\title{
通信ソサイイエテイマガジン 刊行のことば
}

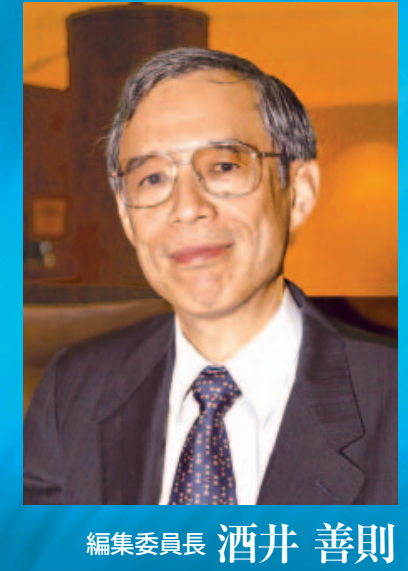

通信ソサイエティマガジン“B-plus”がついに創刊しました．学 会は今までには論文，技術報告，書籍，会誌(現在の学会誌) 等 で会員の皆様に電子情報通信分野の情報をお届けしてまいりま した. 論文, 技術報告(以下論文等) は会員の最新の研究成果を 皆様に提供しているため, 発表, 議論の場と情報提供の場の機 能を同時に果たしていることになります，書籍は学問・技術を体 系的にまとめたものです．これに対して，会誌は最新の技術動 向の提供, 学会活動の紹介を目的としております. 本学会が担 当している学問，技術分野は我が国産業のほとんどすべてで応 用されている広い分野です．このため会誌だけで最新技術動向 の提供するのは困難になりつつあり，商業誌の方が対象分野を 細分化して技術情報を提供しているケ一スも見られます．通信ソ サイエティではこのような現状を考慮して，1年以上前から新し い雑誌, すなわぢ和文マガジン”発行の検討を開始しました。“和 文マガジン”は IEEE のソサイエティ誌をモデルとしております が，委員会ではそれにとらわれることなく，精力的に新しいコン セプトを議論しました.

ます，通信分野を志す学生，通信分野に近い企業の技術者の 方が，少々専門が一致していなくても理解できる内容とすること にしました．ただこれはしべルを下げるわけではなく，筆者に論 文と異なった書き方をお願いすることにより実現しています，内 容としては，まず商業誌でも取り上げられる直近の話題につい て，専門家の立場から客観的に掘り下げて記事とすることにしま した．次に，新しい技術について体系的に分かりやすく解説あ るいはサーベイとして，執筆者の方にはページ制約を厳しく設け ずに，十分な内容をお書き頂く方針を採用しました．これによ り読者から見ると物足りない，筆者から見ると書き足りないこと がなくなることを期待しております．また，純粋技術問題だけで はなく，技術の国際標準化，更には社会的視点も融合した新し い分野についての論述も積極的に掲載する方針としましたここ れらの原稿については，従来学会が対象としていたような技術 内容にオリジナリティがある論文とは別の，論旨の構成，主張 等にオリジナリティがある新しい論文としての位置付けを明確に しています，更には，情報通信分野で優れた業績をあげた諸先 輩に体験談を御執筆頂く，有名な国際会議に焦点を絞つて，開 催された会議の概要を詳細に紹介する等の新しい企画を盛り込
みました. これらの論文, 記事につしては編集委員会で企画す ることはもちろんですが，会員の皆様からの積極的な投稿も期 待する方針です，更に，編集段階からプロの編集者と緊密に相 談して，雑誌のイメージにあった編集を行うとともに B-lus とい う愛称も決まりました.

以上のようなコンセプトに従い創刊号は企画されております. まず先輩の経験談ということで主に大学の研究者にお願いする “私の研究者歴”，企業の技術者にお願しする“私の技術者歴” を 揭載しております．今回は秋山東大名誉教授，立川前 NTTドコ モ社長に御執筆をお願ししました。論評・サーベイ論文として, “光ネットワークの技術動向” を取り上げるとともに，解説として “Web サービス”、“電波伝搬モデル”、“ワンセグ”に関する論文の 御執筆をお願いしております. ご覧になって分かるように，従来 通信ソサイエティで扱っていた中心技術と，必ずしも通信ソサイ エティで中心としてこなかった新しい分野をバランスよく掲載し たつもりでおります．この方針は今後も続ける予定で，通信ソサ イエティ会員の皆様に通信の基盤技術とともに，新しい周辺技 術をきちんと紹介しようとすることを意図しております．更に国 際会議として，昨年末の GLOBECOM に焦点をあて，参加者の 方々による共同執筆をお願し致しました，雑誌の装丁も新しい 雑誌に相応しいデザインを採用したつもりです.

通信分野は大きな変革を遂げようとしております.ブロードバ ンド，ユビキタス，放送・通信の融合等，数年間には環境の飛 躍的変化が予想されます．この時期光通信，ネットワーク，無 線等の従来の基本技術の開発はもちろんですが，これらの標準 化も極めて重要です．更には Web サービスの発展，コンテンツ まで含めた新しい通信ビジネスの動向，関連する制度，法律等 の变革，など技術者にも幅広い知識，見識が要求される時代と なってきました，学会としても技術情報だけではなく，広い分野 の情報を皆様にお届けして，会員相互の議論の場を設けること が重要な務めと考えております．幸い学会には多くの分野で活 躍する会員が多数います. これらの方の御経験を相互に交換す ることで, 会員皆様の知識向上にお役に立てることを期待して おります． 新しいマガジンを読むだけでも学会員でいる意味が あると皆様に思って頂ける雑誌となることが，編集委員一同の 最大の希望です. 